\title{
Strategic Research on the Promotion of Higher Vocational Teachers in the Context of Modern Apprenticeship
}

\author{
Xiaoli Yan ${ }^{1,2}$, Xueli Sun ${ }^{1 *}$ \\ Dalian Vocational and Technical College, LiaoNing Dalian, Code 116035 \\ Dongbei University of Finance and Economics, LiaoNing Dalian, Code 116025 \\ *Brief Introduction of Communication Author: Sun Xueli (1978 -), female, lecturer, Ph.D, mainly \\ engaged in the preparation and application of nanomaterials; higher vocational education and \\ research.
}

Keywords: higher vocational colleges; teachers' quality; quality promotion

\begin{abstract}
Based on the in-depth study of the connotation of the "double-teacher structure" teaching staff under the modern apprenticeship model and the existing problems in the construction of the teaching staff in Vocational colleges, this paper aims at how to create a good environment for the exchange and study of full-time teachers and enterprise technicians, promote the development of the construction of full-time and part-time teachers in colleges, and improve the innovation of the teaching staff in Vocational colleges. In terms of construction, the corresponding strategies and suggestions are put forward.
\end{abstract}

\section{Introduction}

The construction of teaching staff is the foundation of Higher Vocational colleges'foothold and development. In "Opinions on the Pilot Work of Modern Apprenticeship" issued by the Ministry of Education in 2014 (Teaching Achievement No. 9, 2014), it was clearly pointed out that "Building a team of teachers together between schools and enterprises is an important task of the pilot work of modern apprenticeship, and the teaching task of modern apprenticeship must be undertaken by both school teachers and enterprise teachers to form a dual tutorial system". Based on the regional development, Dalian Vocational and Technical College integrates the resources of enterprises and talents in Liaoning Province, explores and practices the platform of "double-teacher workstation" under the mode of "modern apprenticeship" personnel training, and builds a teaching team with strong professional ability and distinctive characteristics of Vocational education. The construction of teaching staff has achieved remarkable results.

\section{The Connotation of the Teachers' Team of "Double Teachers Structure" under the Modern Apprenticeship Model}

The Ministry of Education's "Some Opinions on Improving the Teaching Quality of Higher Vocational Education in an All-round Way" clearly points out that higher vocational colleges should pay attention to the "double-teacher structure" of the teaching staff. "Double-Teacher Structure" mainly embodies in the overall structure and individual structure. It emphasizes that team members should be scientifically and reasonably matched by full-time teachers and part-time teachers. It attaches importance to the rational allocation of teachers'age, expertise and academic affinity, so as to realize resource sharing and complementary advantages among team members, and fully reflects the rationality of teaching team structure. The Notice of the Ministry of Education and the Ministry of Finance on Further Promoting the Implementation of the "National Demonstrative Higher Vocational College Construction Plan" (Teacher's College 2010 No. 8) stipulates that the proportion of dual-quality teachers in demonstrative higher vocational colleges should reach $90 \%$. It makes it clear that dual-quality teachers are mainly determined by quality. 


\section{Research on the Strategy of Promoting Teachers in Higher Vocational Colleges}

\subsection{Problems and Analysis of Teacher Team Construction in Higher Vocational Colleges}

The goal of talent cultivation in higher vocational colleges determines that teachers in higher vocational colleges need not only professional theory teaching ability, but also practical ability in the industry. "Opinion" points out that to improve the quality of higher education in an all-round way, we need to vigorously carry out innovative entrepreneurship teacher training, training, employing entrepreneurs, professional and technical personnel, skilled craftsmen and other diverse components to promote collaborative innovation. In the process of promoting the construction of teachers'team, vocational schools have vigorously implemented the "invite in and go out" teacher training mode, such as internal training and external employment. Although some achievements have been made, there are still some problems in the process of diversification and collaborative innovation of teachers' team.

(1) There are "five no" phenomena in the construction of teachers in Higher Vocational colleges. Higher vocational education has entered a new stage of paying attention to connotation and quality from quantity expansion. The level of teachers'construction in higher vocational education has a direct impact on the quality of personnel training. Due to the insufficient understanding of the multi-component and collaborative innovation of Higher Vocational teachers, there are some problems in the construction of Higher Vocational Teachers in China: the asymmetry between professional knowledge and professional skills, the mismatch between personal treatment and work tasks, the discontinuity between teaching activities and professional practice, the disharmony between self-goal and professional goal, the inconsistency between professional background and professional requirements. The "five no" phenomena such as conformity restrict the further development of Higher Vocational education. 2. The problems existing in the multi-faculty composition of Higher Vocational colleges. (3) The motivation of diversified teachers'collaborative innovation in higher vocational colleges is insufficient. (4) The operation mechanism of multi-development and collaborative innovation is not mature.

\subsection{Improving the Specific Contents of Teachers in Higher Vocational Colleges}

(1) Attaching importance to the cultivation of teachers'ethics and standardizing the level of teachers' professional ethics

The report of the 16th National Congress of the Communist Party of China puts forward the idea of "strengthening the construction of teachers'ranks, improving teachers' morality and professional level". Teachers'morality education has risen to the national will. Higher vocational colleges must attach great importance to the construction of teachers' morality. By organizing various educational activities, such as political learning, seminars, special lectures and audiovisual viewing, teachers should be guided to correctly understand the current economic situation and development prospects of our country, enhance their sense of responsibility and ownership, and regard teacher's morality education as a way to improve teaching. The central issue of teacher quality.

(2) Focus on the Cultivation and Improvement of Teachers'Innovative Ability

Higher vocational colleges should give priority to applied research, guide teachers to carry out horizontal research through various teaching resources projects, and reward "landing" scientific research achievements. The scientific research projects established should be combined with the professional development of teachers and the needs of enterprises. We should take project research as the carrier, promote teachers to serve the needs of enterprises, help enterprises develop corporate culture, improve rules and regulations, carry out enterprise diagnosis, and realize the integration and innovation of teachers'scientific research and enterprises' development needs. In the process of project research, enterprise managers and technicians should be involved to integrate professional theory with social practice, and teachers should learn from each other with enterprise managers and technicians, promote in-depth cooperation between schools and enterprises, and improve teachers'innovative consciousness, innovative ability and scientific research level.

(3) Based on the cooperation between schools and enterprises, "double-qualified" vocational teachers training strategy. 
(1)Analysis of train of thought. In our country, the basic idea of "double-qualified" vocational teachers'training is to take internal incentives as the basic focus, to improve the quality of professional teachers and optimize the structure of double-qualified teachers as the key point, to realize the innovation of education and teaching reform, to enhance the technical service ability, and to improve the teaching and practical ability of professional teachers. Enterprises must play a leading role, make use of relevant professional projects to open channels of cooperation between schools and enterprises, and tract teachers to learn relevant professional theoretical knowledge. In addition, enterprises should regularly send talents to higher vocational colleges to participate in school construction and undertake certain teaching tasks, so as to enhance the teaching ability of Higher Vocational Colleges and make the training of vocational teachers in higher vocational colleges more rational and professional. This is the basic train of thought for the training of "double-type" vocational teachers in China.

(2)Analysis of training objectives. Vocational teachers trained under the "double-qualified" vocational teacher system should possess the following four qualities in order to reflect the comprehensive and comprehensive training of educational talents by the system. Firstly, teachers must possess good ideological and professional qualities, especially the cultivation of professional ethics. Moreover, teachers should fully understand and grasp the industry development trends and the latest technical requirements of the profession they teach, have higher requirements for their theoretical level and teaching experience, and obtain the certification qualifications of university teachers of corresponding professions. Secondly, teachers should have strong basic professional knowledge and corresponding practical ability, and be able to skillfully apply relevant theories to practical teaching activities. Thirdly, teachers should be familiar with the management regulations of relevant industries and be able to teach courses.

To guide students to participate in enterprise management and basic production practice activities. Fourthly, teachers should have strong innovative ability, especially under the guidance of the new curriculum reform education concept in China, be good at accepting new knowledge theory, new technology and new information, and be able to show creative teaching methods in class, so as to help students improve their professional level and expand innovative entrepreneurial activities based on students.

(3)Based on the cooperation between schools and enterprises, "double-qualified" vocational teachers training strategy. Under the environment of school-enterprise cooperation, the training of "double-qualified" vocational teachers must be carried out from the perspective of diversification. This paper mainly discusses the relevant strategies of "double-qualified" vocational teachers'training in Higher Vocational Colleges from the aspects of training content and training mode selection. First, the training strategy based on content selection. We should strengthen the pertinence and applicability of education and training. The training of "double-qualified" vocational teachers must take into account the actual situation of teachers, actively, reasonably, accurately and meticulously use the classification and personalized management model. That is to say, teachers should be trained comprehensively according to their personality, professional experience and educational background. For example, educational psychology, vocational education theory and other courses can improve teachers'teaching ability, while training operation and social activities can experience teachers' teaching practice ability and organizational ability. Therefore, higher vocational colleges must organize practical skills regularly. Training, organizing professional teachers to participate in national and industrial organizations of vocational skills assessment and practical skills operation training activities, in order to broaden the professional horizon of teachers. In addition, we should make rational use of the "school-enterprise cooperation" model, push teachers to the practical positions of enterprises for training, so that they can accumulate certain social and industrial experience, and then pass it on to students in school in the educational work, forming a virtuous circle.For example: Dalian Vocational and Technical College's tourism and hotel management institutes have multi-disciplinary links, joint professional advantages, combined with the region's demand standards for hotel professionals in Higher Vocational colleges, signed orders with several five-star international hotels in Dalian in 2018. Teachers in hotels and teachers jointly 
assume the main body of education. Functions, while allowing teachers to self-study in the process of teaching, in a short time to improve the theoretical and practical level of teachers, "double-type" vocational teacher training system is becoming more and more mature. In addition, on-the-job teacher training should also pay attention to the training of skills operation ability. Higher vocational colleges should unite enterprises and use common resources of both sides to organize skills competitions, entrepreneurship competitions, professional product design competitions and other competitions that can stimulate professional teachers'competitiveness and self-confidence.

\section{Conclusion}

Through the implementation of the training process of modern apprenticeship talents, we can create a "double-teacher teaching team of mutual employment between schools and enterprises", create a good environment for learning, exchanging and cooperative research between enterprise technicians and college teachers, and effectively promote the construction of the teaching staff. In theory, it enriches the new connotation of the construction of teaching staff under the modern apprenticeship mode, provides a brand-new platform for the training of teaching staff in practice, innovates the ways of the construction of teaching staff in Higher Vocational colleges, and opens up a new road for the construction of teaching staff in Higher Vocational Colleges in China.

\section{References}

[1] Ministry of Education: Several Opinions on Improving the Quality of Higher Education in an All-round Way, 2012-04-23. http://www.edu.cn/gao-jiao-788/20120423/t20120423-768680.shtml.

[2] Chen Jiangwei, Five Phenomena of "Double-qualified" Teachers in Higher Vocational Colleges and Ways to Improve Their Practical Ability, China Electric Power Education, No. 11, 2010.

[3] Han Bing, Li Lin. Problems and optimization of faculty building in Higher Vocational Colleges in the new era [J]. Education and teaching research, 2015 (9): 37-39.

[4] Li Lianwei. Structure and optimization of teaching staff in Higher Vocational Colleges in China [J]. Education and occupation, 2015 (12): 64-66. 